\title{
Bank Risk Measurement: A Critical Evaluation at a European Bank
}

\author{
Gunnar Wahlström ${ }^{1}$ \\ 1 Gothenburg Research Institute, School of Business, Economics and Law, University of Gothenburg, Övre \\ Fogelbergsgatan 6, Box 603, SE 40530 Gothenburg, Sweden \\ Correspondence: Gunnar Wahlström, Gothenburg Research Institute, School of Business, Economics and Law, \\ University of Gothenburg, Övre Fogelbergsgatan 6, Box 603, SE 40530 Gothenburg, Sweden. E-mail: \\ gunnar.wahlstrom@gri.gu.se
}

Received: May 17, 2013

Accepted: June 7, 2013

Online Published: June 13, 2013

doi:10.5430/afr.v2n3p24

URL: http://dx.doi.org/10.5430/afr.v2n3p24

\begin{abstract}
This article assesses bank management's perspective on the use and effectiveness of the risk measurement system under Basel II that setcapital requirements for banks. These requirements encouraged the use of risk measurement. Semi-structured interviews with various bank managers at Viking Bank (a fictitious name) provide the empirical data for this research. These interviews were conducted after the global financial crisis that led, among other events, to the bankruptcy of Lehman Brothers. Viking Bank was an important European bank that embraced Basel II and risk measurement. In its efforts to implement risk measurement, the bank's management accounting department was reduced and subordinated to the risk measurement department. Risk measurement information became the bank's primary source of information for some loans. However, in their decision-making, managers showed mixed support for risk measurement that had, in some instances, become disconnected from operations. For other loans, they preferred to use their so-called Expert Judgement. The narrow and limited career paths available for the risk measurement specialists also reflected the decreased influence of risk measurement on decision-making at the bank.
\end{abstract}

Keywords: Risk measurement, Basel II, Bank

The financial crisis has made us more reluctant to use risk measurement. This was not the case before the crisis hit us. (Senior bank manager, Internal Auditing, Viking Bank)

\section{Introduction}

The Basel Committee on Banking Supervision's second Basel Accord (Basel II) recommends risk measurement guidelines that banks can use to set their minimum capital requirements. In the European Union, Basel II is implemented by Directives 2006/48/EC and 2006/49/EC. These Directives were adopted in 2006 and came into force on 1 January 2007. The main difference between Basel II and its predecessor, Basel I, is that Basel II encourages bank officers to take risk measurement into consideration in their daily operational decisions. The incentive for banks to use risk measurement is that, under Basel II, they may be able to reduce their capital reserves. With more capital available for investment, banks may thus increase their investment yield (ceteris paribus). (Note 1) Nevertheless, serious doubts have been raised about the regulation of banks and their use of risk measurement (Beck, 1992; Mikes, 2009; 2011; McGoun, 1992; 1995; Power, 2004; 2007; 2009). These doubts are discussed in the literature review below.

Today the four listed banks in the European country of this study have implemented risk measurement systems for use in daily decision-making. Despite its very advanced risk measurement system, one of these banks, Viking Bank, (Note 2) nearly failed following the collapse of Lehman Brothers in 2008. However, Viking Bank's use of risk measurement information in the crisis has not been thoroughly examined. In this context, this article addresses three issues: first, the accounting management issue (Note 3) related to how bank managers react to the imposition of international regulations; second, the management issue of whether bank managers trust the risk management information they receive; and third, the personnel issue of career opportunities for risk measurement specialists.

It has been claimed that in the financial crisis following the failure of Lehman Brothers in

2008, management accounting has not been received the criticism it may deserve. As an example, the U.S.

Congressional reports on the financial crisis (The Financial Crisis Inquiry Report. 2011, Wall Street and the Financial 
Crisis, 2011) do not address the management accounting issue. Rather, they conclude that the crisis was an avoidable management crisis. However, because management accounting is the source of essential information, senior bank managers cannot afford to neglect it. The information provided by management accounting may help management avoid such crises.

Viking Bank was the first bank in the European country of this study to receive approval for the use of risk measurement as the justification for setting capital requirements (per Basel II recommendations). According to the EU Directives 2006/48/EC and 2006/49/EC, the national regulatory authority decides if a bank, after application, can measure its minimum capital requirement using risk measurement tools or if a more "blunt" risk assessment should be used. The banking community acknowledged that, amongst the models used by the country's banks, Viking Bank's sophisticated models produced the most reliable information.

This study is based on interviews with Viking Bank personnel that were conducted in two phases. In early 2009, interviews were conducted with 17 senior bank managers. In early 2010, the research site was revisited and an additional 15 interviews were conducted. In addition, four interviews with representatives from the Financial Supervisory Authority and a rating agency were conducted in the second phase of interviews.

The consequences for Viking Bank after the financial crisis of 2008-2009 were dramatic. In the transition towards risk measurement, various risk measurement tasks were assigned to the Management Accounting Department. The Department's work revealed there was insufficient time allotted for identification of the potential risks. As a result, because Viking Bank's managers lacked reliable information on operations., their support for risk measurement weakened. Risk measurement, as a career speciality, was problematic, even for ambitious staff members with good academic records and good work histories. Consequently, because risk measurement is essential for meeting regulatory standards, there was a gap between practice and regulation. Although senior bank managers embraced the requirements of Basel I, they did not embrace risk measurement system.

Viking Bank's experience is not unique in the banking/financial industry. Viking Bank was only one of many banks and financial institutions that suffered from the worldwide market failure. Yet it is an unresolved question to what extent Viking Bank's financial crisis resulted from this market failure. In any case, there is no doubt there were problems at Viking Bank related to its use of the Basel II risk measurement system. This article assesses management's perspective on the use and effectiveness of the risk measurement system under Basel II.

The article is structured as follows: The next section is a literature review, followed by background information on Basel I and Basel II. Then the research method is presented, followed by a description of Viking Bank. Thereafter, the findings and a discussion of the findings are presented. The article concludes with comments on the contribution of this research to the literature and suggestions for future research.

\section{Literature Review}

Some risks in banking are assessed while others are measured. Risk assessment has always been a natural part of business management where risks are evaluated in the pursuit of good deals. Compared to the assessment of risk, the measurement of risk is quite a new phenomenon even though risk measurement was first discussed in the literature in the 1920s and gained a strong foothold in the academic world in the 1950s (McGoun, 1992; 1995). Risk measurement in practice, which has emerged as a widespread if not a dominant practice in financial institutions, is today an accepted part of business information systems (Bhimani, 2009; Chua, 1996; Kaplan, 2009; Mikes, 2009).

It is commonly assumed there are three levels of enterprise risk that are categorized according to the predictability, controllability and manageability of their consequences (Kaplan, 2009). Level 1 risks are the global business risks that are difficult to predict but can be potentially devastating in their effect. Level 2 risks are the risks inherent in an enterprise's strategic decisions; such risks are accepted as a natural fact in the pursuit of superior returns. In taking Level 2 risks, management tries to minimize the likelihood of negative results and to mitigate such results if they occur. Level 3 risks are the known and avoidable risks. Basel II primarily concerns Level 3 risks that it clearly defines as credit, market and operational risks. (Note 4) In practice, Value-at-Risk (VaR) models are accepted as suitable measurement tools for Level 3 risks.

According to McGoun (1995), risk measurement models, which are used in the evaluation of credit, market and operational risks, should be based in practical concerns and not on speculative assumptions. Otherwise such models will fail in crisis situations (i.e., when bank activities differ from theoretical hypotheses, leaving managers without support). McGoun argues that if such speculative assumptions were subjected to critical review in open debate, risk measurement models would soon be abandoned. As this criticism of the use of risk measurement models is severe, we need to take a closer look at McGoun's charges against three widely held assumptions: (1) the belief that historical 
values can be used to forecast the future; (2) the neglect of 'the law of large numbers'; and (3) the conviction that risk estimations are knowable.

The difficulty with the first assumption is in identifying the historical conditions, if any, that are sufficiently similar to current conditions to allow a projection of the future. As far as the future, the only certainty is that it will be different from the present or the past. The uncertainty about the future makes historical assumptions problematic. The second assumption refers to the neglect of 'the law of large numbers', which predicts that the expected value will occur in the long run. With such neglect, there is no recognition that measures such as standard deviations may become obsolete. If there are a large numbers of observations, the standard deviation moves close to zero, making the risk measure of no informational value. Similarly, there is a problem with the third assumption related to the certainty of risk estimation. An investor who must choose between two investments, both with a yield of 5\% and both with a risk measure (e.g., a standard deviation) of 2, may still prefer one investment to the other. The investor may see a greater risk with one investment owing to expectations about future events. If we are to understand every investor's vision of the future, we need to probe every investor's brain. Of course, this is not possible. Nevertheless, despite the problems that McGoun identifies with these three assumptions that underpin risk measurement models, regulatory authorities continue to impose risk measurement requirements on banks.

The literature identifies another factor that should be considered in the discussion of risk measurement by banks. In his study of risk measurement, Danielsson (2002) discusses the reasons behind financial institutions' capital requirements and shows how such institutions are affected in financial crises. In revealing the flaws in risk measurement, he concludes that risk measurement may actually worsen the financial situation for a financial institution in crisis. Clearly, such conclusions create concerns about the use of risk measurement.

Recently, there has been a debate on risk measurement (Bhimani, 2009; Mikes, 2009; Woods, 2009). Bhimani states there are no field studies that critically interpret bank managers' opinions of risk measurement. Mikes recommends that researchers conduct studies that interpret such opinions. Woods encourages us to study the influence of central policy over control systems, and claims that the effectiveness of control systems, such as risk measurement, depends not only on their overall design but also on the controls that are implemented.

According to Ulrich Beck (1992), risk regulation is not useful for measuring and dealing with risk. Severe financial risks may emerge that can be of such magnitude that they can threaten the survival of banks. If risks can be regulated, then the assumption must be that they can be identified. The evidence from financial crises indicates, however, that risks are not always foreseeable because of the dynamic forces in a capitalistic system. If risks were foreseeable, management would take avoidance steps to protect their organizations. Therefore, a softer culture of values should regulate the framework for risk regulation. Such a culture can continuously deal with previously unidentified or neglected risks since it can adjust to the new conditions that a culture of static, numerical risk identification cannot. A static culture will not survive because it does not allow an organization to adjust.

Power (2009) states that regulators' professionalization and their legitimacy agenda influence risk management. The specific advantages of risk management then become less important. Consequently, the regulation of risk is a risk in itself because the action of risk measurement can produce a false sense of security in management.

In a comparison of two banks, Mikes (2009) concludes that top management in one bank listened to the chief risk officer who did not use risk measurement information. At the other bank, when the chief risk officer used risk measurement information in his presentations, top management did not listen to his presentations. This study contains a warning about the effects of the shift towards risk measurement by bank management.

Risk experts act differently in their various activities (Mikes, 2011). In banking, depending on whether banks use decentralized or centralized risk management, their risk measurement functions may differ (Wahlström, 2009). The five banks in Mikes's (2011) study had similar structural arrangements and used similar risk management techniques, but the banks' management handled risk information quite differently. Because managerial characteristics and practices in banks differ significantly, bank managers will not treat risk measurement information similarly. This difference suggests that Basel II can be problematic because the regulatory framework prescribes and rewards the use of risk measurement information in daily decision-making.

The rise of risk measurement in banks suggests a continuing ambition to control and manage the future (Power, 2007). Risk management in banking has thus resulted in an increased emphasis on internal control as well as the creation of new risk categories and new managerial tasks. This development, with its increased demands related to decision-making and control, has created new professions and altered work for others. These new risk management policies and routines mean that risk measurement is today much more widespread than in past years. 
Power (2009) argues that this development, with organizational governance strongly influenced by concern over risk, is not merely a technical development. He claims that this development may define good governance in all phases of organizational life. Risk measurement then may displace valuable but vulnerable professional judgment (Power, 2004). Such a development may also affect employees' commitment. With less commitment, the quality and quantity of their work may diminish as their responsibility diminishes. Institutionalization of risk measurement may then endanger individual employee accountability.

In its emphasis on risk measurement, Basel II intends that banking regulators expand risk measurement from a specific instrument of governance to an entire rationale for governance. According to Power (2007), however, we still know very little about this shift. There are few studies that investigate risk measurement in action, especially in instances of financial crisis.

The ambition to measure everything (Power, 2004) is closely related to the ambition to manage the risk of everything. This ambition as far as risk management reflects the efforts by organizational agents to decrease their personal risk. The result is potentially disastrous for society as employee judgment shrinks to an empty form of defendable compliance. Risk management of everything also poses a major risk to society because the most pressing and unpredictable problems cannot be solved without marshalling the knowledge and judgment of experts. In such cases, managers must take a central role.

The implementation of Basel II has increased the role of internal control in banks (Power, 2004). Regulation is considered more effective and acceptable if implemented in private control systems. The idea is that regulatory organizations can be relieved of detailed rule making and can instead focus on the design and function of local systems. In this effort, risk measurement has to be auditable and governable. As a result, there has been a change in the supervisory role in banks as internal conditions and organizational trustworthiness are emphasized (Power, 2007). Such change fosters the design of risk management of everything. The point is that Basel II has worked through internal controls to encourage regulation compliance for risk measurement. However, the difference in management characteristics has been neglected.

Power $(2004 ; 2007 ; 2009)$ criticizes the legitimacy agenda of various control agents that drive risk management. This criticism is examined in this article. The financial crisis that began in 2008, like all such crises, was proof that it was not possible to work as before. It may be asked whether bank managers were better at assessing the use and effectiveness of risk measurement systems under Basel II after the financial crisis of 2008. Financial crises have been a major force in the implementation of risk management (Power, 2007; 2009) as well as in risk measurement, but the measurement of risk has not yet been challenged in a banking crisis. If bank managers base their decision-making on international regulations, it is not necessarily the case that they will escape criticism and political interference (e.g., government takeover). Compliance with regulations, even burdensome regulations, may give management a false sense of safety. Instead of doing what is best for the organization in the long run, managers may adopt a seriously flawed decision system. The assumptions behind such actions have not been adequately discussed.

Risk measurement holds the promise of manageability (Power, 2004). There is a functional and political need to sustain the myths of control and manageability despite the complex failures, scandals and disasters that have challenged and threatened organizations. These problems are so complex that that no single control system can manage them (Beck, 1992: Power 2004; 2007).

Bank regulators emphasize measurement of risk in all its forms. Other concerns, including political problems, also arise in the banking industry, but they do not relate to the banking capital requirements. Basel II, which is concerned with credit, market and operational risks, imposes various administrative routines. These routines, when complied with, may give management a false sense of security and the opportunity to escape responsibility. Thus, regulation may contribute to poor management practices and decisions. A bank that fails is a failure of management in which the focus on risk measurement may take priority over other management concerns.

Beck (2002) and Power (2004; 2007; 2009) criticize rational risk governance as a technocratic system and a bureaucratic defence against anxiety. However, there is as yet little evidence on how users understand and use risk measurement in their everyday work (Bhimani, 2009; Chua, 1996; Kaplan, 2009; Mikes, 2009). In fact, in the Scandinavian countries, as recently as ten years ago, listed banks did not use risk measurement tools; risk measure was considered an ancient science (Mikes, 2009; 2011). Risk measurement has also been described as an administrative and managerial fashion (Power, 2004). Such opinions raise other questions about risk measurement. One question is: What is the career trajectory for individuals who work with risk measurement? There is a suggestion that risk measurement specialists, who are skilled in mathematics and statistics, have become modelling experts in a specialized profession. 


\section{Basel I and Basel II - The Experience}

National regulators in the 1970s and 1980s (e.g., the Securities and Exchange Commission and the Federal Reserve Bank in the United States) were concerned that internationally active banks operated with lower and lower levels of capital (Kapstein, 1989). One response was the founding of the Basel Committee on Banking Supervision (the Committee), established in 1974 by the central bank governors of ten nations. The Committee, whose purpose was to issue banking guidelines and best practice standards, approved and released the first Basel Accord, Basel I, to the banks in July of 1988. Many nations adopted Basel I, which set minimal capital requirements for banks. Initially some observers said Basel I was the most important international banking agreement in recent years (Cerney, 1994). However, in time the financial industry agreed that Basel I was too blunt as a regulatory instrument because it did not give sufficient consideration to banks' risk measurement practices (Basel Committee, 1999; 2001a; 2001b). This criticism of Basel I led to the release of the second Basel Accord, Basel II, in 2004. In 2006, in a Directive, the European Union adopted Basel II for use by banks in the member states.

Basel II provides significant economic incentives for banks to use risk measurement tools for gathering the information needed for their daily activities. According to the Basel II guidelines, a bank may operate with a lower capital requirement if its regulatory authority judges the bank's risk management system is sufficiently advanced. With a lower capital requirement, a bank can invest more of its capital. With greater returns on invested capital, Basel II reasoned, banks might lower their customer fees and become more competitive.

According to many bank managers the lower capital requirement incentive was critical to the survival of their banks. When the Basel II guidelines were issued, there was a commonly held belief among bankers that they were facing lower and lower margins (Wahlström, 2009). Some bankers thought that the adoption of an advanced risk management system that used sophisticated risk measurement tools aimed at making better credit decisions would allow them to reduce their capital requirement level. Implementing such a system, which would free up capital reserves for investments, could give them a competitive advantage over banks that did not use such sophisticated risk measurement tools.

\section{Research Question, Method and Case Study Setting}

The research question of this study is the following: What is management's perspective on the use and effectiveness of the risk measurement system imposed by Basel II? Thus this study questions the core rationale of risk measurement. To try and answer this question, 17 senior bank managers at Viking Bank were interviewed in the first six months of 2009. The major finding of the initial round of interviews was that the system provoked a false sense of security in Viking Bank's management. To confirm this finding, the bank was revisited a year later in 2010. At that time, 15 senior bank managers, three supervisory authority managers and one rating agency analyst were interviewed. The major finding of the initial round of interviews was that the system provoked a false sense of security in Viking Bank's management. To confirm this finding, the case study site was revisited in 2010.

The interviewees were division heads, the Treasury manager, senior credit staff, financial managers, senior risk managers and other executives. In addition, four representatives from regulatory and rating organizations were interviewed. The interviews continued until the interviewees repeated responses; at that point, saturation was achieved (Glaser \& Strauss, 1967) and the interviews concluded. Each interview lasted an average of 40-60 minutes.

There is a debate on the merits of the interview as a data collection method, particularly when the issues are sensitive, even political. Given Viking Bank's negative cash flow, its losses and its high Cost to Income (C/I) ratio at the time of the first round of interviews, there was indeed turmoil at the bank. Such turmoil in a for-profit entity may affect employees' interview responses. They may be cautious, fearful and not entirely forthright. For this reason, I rejected the use of anonymous, written questionnaires. Instead, I conducted only face-to-face interviews in order to promote a relationship of trust with the interviewees. In the second round of interviews, when the financial distress had eased and Viking Bank's key ratios had improved, I interviewed the same individuals I had interviewed previously.

This interview/re-interview strategy was effective in that, by the second round, I was no longer a stranger to the interviewees. In my interviews that dealt with the core rationale of risk measurement, unavoidably I asked sensitive questions. However, as a certain level of trust was established between us, the interviewees, who may have had doubts about risk measurement, seemed to welcome the opportunity to speak freely even though they had not expressed their doubts to their colleagues.

I used the semi-structured interview form in which interviewees are encouraged to give extensive responses to general questions in a conversational format (Hartley, 2004; King, 2004; Kvale, 1983) that allows the phenomena under study to become visible. When the interviewees gave thought-provoking responses, I could ask additional questions that 
explored the area or issue further. Although this interview technique is demanding, both for the interviewees as well as the interviewer, its advantage is that responses are more likely to be reliable. An indication of the reliability of the responses in this study is that the interviewees expressed both positive and negative opinions on the risk measurement system.

My literature review also influenced my selection of interviewees. First, because Viking Bank management took a greater interest in risk measurement following a process of centralised decision-making, I found it worthwhile to interview staff members at headquarters as well as at the branches. Second, although risk measurement is an ancient science, as Mikes $(2009 ; 2011)$ states, we do not know much about it in practice. Thus I wanted to understand how various bank managers implemented risk measurement in their daily work, and if they found it a useful tool.

For my analysis of the interviews, I used a recommended methodology to examine the interviewees' experience with risk measurement during and after a financial crisis (see Bryman \& Bell, 2003; Hartley, 2004; King, 2004). Immediately after each interview, I summarized it in a few keywords in order to obtain a general idea of the most important ideas expressed by the interviewees. Then I transcribed the interviews and summarized each paragraph by one keyword. Next, using these keywords, I grouped the paragraphs and condensed them into fewer paragraphs. The keywords I ultimately used are 'Support', 'Management tool', 'Decisions', and 'Influence'. The main theme in the interviews concerned the erosion of trust in the risk measurement system at Viking Bank.

\section{Viking Bank}

I chose Viking Bank as the case study site for several reasons. First, in the late 1990s, when Viking Bank implemented a risk measurement system, it was the first bank among its competitors to do so. Viking Bank's Board of Directors and top management embraced the drafts of Basel II as a step in right direction. Thus, several years before its main competitors, Viking Bank had a risk measurement system in place for decision-making. Within the banking community, Viking Bank was regarded as the most sophisticated bank in this respect. The national regulatory authority for banking approved Viking Bank's risk measurement system as one of the most advanced under the stipulations of Basel II. Second, the banking community admired Viking Bank's risk measurement system. Other banks asked Viking Bank for advice when designing their risk measurements systems. Third, Viking Bank was open to academic research and permitted researcher access to people with experience in risk measurement.

Viking Bank, which was founded over 150 years ago, is today the result of some 120 mergers and acquisitions. Viking Bank has enjoyed a close connection with the national Government over the years, regardless of whether a liberal or conservative coalition has governed. In general, society regards Viking Bank as a symbol of capitalism in a socialist country. As might be expected, the country's wealthier citizens make up its main retail customer base. Traditionally. Viking Bank has had a centralised management structure, and as recently as the 1980 s, the Board met every week to review each promissory note.

Forty years ago, following a merger that was a response to tighter national bank regulations, Viking Bank emerged as both a commercial bank for business customers and a retail bank for private customers, with branches throughout country. In recent years, the retail division of Viking Bank has not been a top priority. In the year 2000, Viking Bank even considered giving up the unprofitable private mortgage lending activity. However, with the lower capital requirements that Basel II permitted, mortgage lending again seemed profitable, and the activity was retained. In addition, home mortgages in banking are viewed today as a sales channel for other products such as home insurance, credit card lending and personal accounts. By contrast, the viability and profitability of Viking Bank's commercial division has never been in doubt.

In the early 1990s, when the risk measurement movement began, a nationwide financial crisis threatened Viking Bank. During that crisis, when the country's central bank set its interest rate at 500\%, three of the country's four listed banks applied for, or considered applying for, financial support from the Government as their credit losses mounted. Viking Bank prepared a request for such support, but it was never submitted. When the early twenty-first century financial crisis arose, Viking Bank's major shareholders and its top management team were anxious to avoid a repeat of the situation in the 1990s when they almost lost control of the bank. . Banks in the country that received financial support had to issue common stock to the Government.

In 1965, Viking Bank started to expand internationally by opening branches in London and Geneva, followed by expansion in the 1970s and 1980s into other European cities, Asia and the United States. As its international activity increased, in the late 1990s Viking Bank launched e-banking, which allowed it to close some local branches. In 1997, Viking Bank bought an insurance company, and in 1999 it bought a German bank of equal size. However, the German acquisition has been troublesome and has not developed as intended. Between 1998 and 2000, Viking Bank expanded 
rapidly in Eastern Europe, mainly in the Baltic countries, Poland and Ukraine. Viking Bank's goal was to gain a significant market share quickly in this fast-growing area by buying local banks and adapting them to its own culture.

Because of this expansion activity, Viking Bank describes itself as an international banking group and a finance group in northern Europe with international operations. However, in 2008 and 2009, with the global financial markets facing crisis, the Eastern Europe expansion began to seem more a burden than an opportunity. Although it may take Viking Bank some years to resolve these problems with the Eastern European expansion, Viking Bank has recovered from difficult situations before. For example, in 1932, following the Krueger Crash, the Government intervened to support the bank. And in 1993, when the country's real estate bubble burst, the Government again provided assistance.

As Viking Bank grew domestically and expanded internationally, it spent millions of Euros to develop and implement a risk management system that complied with the Basel II guidelines and the recommendations from its national regulatory authority. Generally, senior bank managers as well as new hires took pride in the new system. For young staff members in particular, many of whom had just completed their doctoral studies but had limited work experience, Viking Bank's risk measurement system seemed very attractive. Nevertheless, despite the hope and even promise of the new system, in the early twenty-first century Viking Bank, like many banks worldwide, faced a severe liquidity crisis.

No company likes to be forced to seek equity capital contributions. However, this was the position Viking Bank found itself in after increasing its dividend payout and purchasing its own shares. As a result of these actions, Viking Bank had a thin capital base when the financial crisis of 2008-2009 began. In addition, Viking Bank's possible credit losses in the Baltic States, Ukraine and Germany, which were widely discussed in the business press, were a grave concern. Adding to the difficulty was that in three years there had been a complete turnover of all middle managers at the bank, draining it of valuable competences. Finally, when Viking Bank had to ask shareholders for a capital injection, its share price declined by $90 \%$. Shareholders could take little comfort in the previous dividend payout record. The lesson is that an emphasis on key ratios, such as $\mathrm{P} / \mathrm{E}$, combined with shareholder pressure, can push management to take excessive risks. Viking Bank tried to satisfy its shareholders by taking short-term measures (generous dividends and share buy-backs that raised the $\mathrm{P} / \mathrm{E}$ ratio). As a consequence, the shareholders' equity of Viking Bank was reduced to a point that threatened its survival when credit tightened and losses increased.

\section{Findings}

\subsection{The Shift to Risk Measurement from Management Accounting Information}

Given this scenario, Viking Bank's managers were fearful of losing control of the bank as it almost had following the financial crisis of the 1990s. After Viking Bank's survival of the crisis in 1990s, new top managers were employed. These managers, who were convinced that risk measurement was necessary in decision-making, strongly supported a shift from the use of management accounting information to risk measurement. The Basel II project manager at Viking Bank described the shift:

Basel II is a step forward in the regulation of banks from a risk perspective. Moving from the accounting perspective has not been easy. Accounting numbers can be manipulated, and the rules of accounting constantly change. With a risk-based formula, we are able to maintain an appropriate level of capital. As a concept for risk measurement, Basel II is excellent. With Basel II or Basel III, more general standards will not be needed. In the near future, we will see that banks have to operate with parallel systems: leverage ratios and risk measurement. In twenty years we will laugh that we thought banks should use leverage measurements instead of proper risk analysis.

The shift from management accounting information to risk measurement influenced how Viking Bank operated. A manager (and an assistant to the CEO) of a division that accounts for about $50-60 \%$ of the total bank turnover commented:

Yes, you are right. We have seen a shift to a risk measurement perspective. As an example, consider our business team. Previously our business team consisted of an accountant and other business people. In addition to these people, the team now has a risk-adjusted performance person. In a business deal decision, the risk-adjusted performance person's views are more important than those of other team members.

The Treasury manager made the following comment on the transformation from accounting information to risk measurement:

Basel II has been a step in the right direction. At the bank, the shift towards risk-adjusted yield has been seen as a step forward. Of course, this has led to the increased importance of risk measurement at the bank over the last ten years. 
Accounting people have had to adjust to this changed condition. From my point of view, this [the shift toward risk-adjusted yield] has not been a problem.

Because senior bank managers favoured risk measurement information over management accounting information, the Management Accounting Department at Viking Bank was eventually dissolved. The remaining employees from the Management Accounting Department were assigned work that dealt with issues related to risk measurement rather than to purely accounting issues. According to the Treasury manager, the accounting function at Viking Bank was no longer considered a serious source of useful information for bank operations. He explained:

We will have more models that provide us better standardisation throughout the whole bank. The size of the group developing models for Basel II will remain intact because Basel II is a step forward towards achieving better economic results. Decisions based on risk measurement lead to improved decisions. Using only accounting information, based on some sort of historical valuations, is a certain way to drive the bank off the road.

At Viking Bank, it is clear that risk measurement information had taken priority over accounting information. Top management at Viking Bank viewed risk measurement as the best way to produce the crucial information needed to avoid a future financial crisis. However, over time, especially due to the crisis of 2008-2009 and the failure of Lehman Brothers, support for risk measurement was divided.

\subsection{Divided Support for Risk Measurement}

Management support for risk measurement generally depended on the type of loans Viking Bank made. For loans to private individuals, including mortgages, risk measurement seemed to work well. According to national law in the country where Viking Bank is incorporated, a loan is secured by the borrower and not by the items acquired or the real estate mortgaged. For example, a bank will seek repayment from the borrower if a house is sold for less than the outstanding mortgage balance. However, it is not possible for the borrower to just walk away from the mortgaged property. Thus, risk measurement is useful for evaluating private individuals' risk of default.

Viking Bank managers also supported the use of risk measurement for personal loans to private individuals. They could evaluate the creditworthiness of individuals by referring to a leading credit rating organization that provides information on individuals' credit history, assets, income tax data, and so forth. The managers said the lack of access to such information in the Baltic States was the main reason for the severe difficulties that arose in 2008.

Nevertheless, for other types of loans, the managers' support for risk measurements was more cautious. A senior adviser to the CEO said:

If you only look at the statistics, you will probably be wrong. At this bank we try to apply something that we call Expert Judgement. We try to use our heads. In retail, we have 95\% trust in risk measurement information, but we have only 5\% trust in Expert Judgement. It is too expensive to use Expert Judgement for en masse credit. For larger loans, it is the opposite relationship. For these credit decisions, we trust risk measurement at 5\% and Expert Judgement at 95\%. Pressing a button for statistical information gives you only a small part of the information you need. I would never rely solely on that information, except for small loans to private individuals.

A major reason for the lack of support for risk measurement for loans (other than retail loans) was the doubt about the information used in the risk measurement models. One risk expert said:

I believe that the statistical models do not deliver the truth. When we use Basel II we only have the bond defaults in the USA from the sixties and seventies to build on. How useful is that information for managers? Basel II must be allowed to live another five or six years, so a number of business cycles are captured. It is very dangerous to say that now that we have had Basel II, we can use it. Getting historical data has been the biggest problem; it is too limited and not of sufficient quality. Also, acquiring such data takes time and is an aggravation. Like most banks, we have a complex legal structure and a complex geographic system, which means that the systems are not located in a centralised warehouse.

Although a system of models may be strongly rooted in a bank's policies, users may not necessarily find the information useful. One branch risk manager said:

A conservative interpretation is that we have not seen how the models work through a whole economic cycle. It is not yet proven that the prediction level is high. Models are only models.

Another problem is that data series from brief time periods may create the suspicion that risk measurement information is unreliable. Managers who are suspicious of information are unlikely to rely on it, especially if they are responsible for decisions based on that information. The highest ranked officer in the Loan Department and a member of the management committee described his experience with risk measurement: 
Risk measurement is like driving a car in a city you not have been in before. You get driving instructions from someone who is just looking out the back window. You get information too late.

Moreover, information from risk measurement is based on historic numbers. When users experience situations that have not previously been recorded, risk measurement is unable to provide support for decisions. Thus it is unsurprising that the support for risk measurement weakened at Viking Bank. The same loan officer described how the information from risk measurement should be used:

I don't want the risk measurement staff to be involved in credit decisions. They should be statistically oriented. I want them to sit in the chairs behind their desks.

A loan to a business is based on specific factors unique to that business, while risk measurement is based on generalized statistical data. This makes risk measurement difficult to use. A manager who reported directly to the CEO explained the problem:

On average you can get risk measurement systems to work very well. From a pool of 100, 200 or 300 companies, you can get a reliable average. But the average says nothing about the individual cases. A credit decision is a decision for an individual. This is the reason that such systems do not work.

When someone states that a risk measurement system does not work, the implication is that there is a problem with the information that Basel II is intended to produce. This was the situation at Viking Bank following the financial crisis that began in 2008. Managers at Viking Bank were sceptical of the value of the risk measurement system. As a fallback solution, Viking Bank introduced the use of Expert Judgment to evaluate the risk in its loan portfolio.

\subsection{Viking Bank Staff and Their Work with Risk Measurement}

The effect of the risk measurement system as a management tool was quite evident as far as Viking Bank's staffing. In the past, when the bank reduced staff and cut programs, various areas suffered (e.g., accounting and auditing). However, risk measurement staff members were not affected; in fact, their numbers, as well as their salaries, increased.

In 2000, very few people at Viking Bank worked in risk measurement- By January of 2009, the bank employed 130 persons at headquarters in risk measurement. Today, as many people work with risk measurement as with accounting/financial issues. (Note 5) In addition, there are more people at the branches who work with risk measurement than work with traditional accounting/financial issues. The Viking Bank project manager for Basel II described the change:

When I joined the bank in 2003, we had a group of five people in risk measurement and maybe 25 more people in trading. That was seen as sufficient. Now we have 130 people, and a lot of them were hired because of the need to comply with Basel II. It is now necessary to hire people who are able to model risk, who have good statistics knowledge and who are able to interpret the rules.

It may seem initially that risk management is a good area for new university graduates to begin employment. They may rise to key positions at a bank with a 150-year history. They may be involved with producing information essential for decision-making at various managerial levels--from the Board of Directors down to the branches. However, based on the interviews, it seems that risk measurement offers a rather bleak career path. The risk measurement specialists were often overlooked when promotions were made. The reason may be that they are employed soon after graduation from university or are promoted from a junior position in marketing or IT. Thus, they often lack the banking experience and/or the management skills necessary to advance in the managerial hierarchy. The risk measurement chief described this situation:

Nearly all my staff members are risk measurement professionals. Only a few of them have management skills, and almost no one has any business skills. They are often recruited from a marketing position, or straight from university, or from the field of IT. Without a business background, they face great difficulty in advancing in the organization.

To address the problem of career advancement in the area of risk measurement, Viking Bank decided different levels of risk measurement specialists were needed. The risk management chief continued:

As a bank, we are trying to create some sort of seniority of specialists. Our idea is that a staff member could become a senior risk measurement specialist who might earn as much as 100000 crowns a month. A high-risk measurement specialist earns much more than that, but that compensation should be a possibility for a super, top-risk measurement specialist. Until now in the banking industry, that sort of money has been reserved for 100, 200, 300 people with profit responsibility. So that's a goal. I would like to see, and we lack this in the risk measurement area, is more people with economics degrees and business experience. I mean people who actually, for example, are in credit risk modelling, I would like to have more people who have lent money, have dealt with customers and have understood the data. 
At present, Viking Bank, risk measurement staff members have to change positions if they wish to advance (with commensurate increases in compensation). Often they have to take a position at a lower level, in another area, in order to advance in the bank.

\subsection{More Criticism of Basel II}

In the 2008-2009 financial crisis, when Viking Bank was following the Basel II guidelines, lending activity decreased as losses increased. As a result, the bank was forced to set aside more funds in order to meet the capital requirements. A senior bank branch manager said:

The difficulty with Basel II is that it allows banks to operate with lower amounts of capital. If you look at yourself as a private person or a large company, when times are good you save for when times are bad. But Basel II works just the opposite in several ways. So when times are bad, you have to save and reduce the loan activity. Because revenues are lower, you need to increase your capital. Risk measurement is a theory that does not hold.

This statement suggests the problem is the method of risk measurement. When a financial crisis arises, it is the result of previously, unidentified risks. In other instances, there is no crisis.

According to the interviewees, the financial crisis revealed another deficiency of Basel II. Because Basel II does not address liquidity risk, its models could not predict the liquidity crisis that the banking industry experienced in 2008-2009.

Since risk measurement uses market values, it is sensitive to market movements. The interviewees said they were shocked by the dramatic downward turn in share prices in the global financial crisis of 2008-2009. They said they had not experienced such volatility before. Therefore they were cautious about the market's valuation of assets for collateralized loans. One branch manager said:

The association of market values and Basel II has proven to be dangerous. With a leverage ratio of 40-50 times, a few of the present capital requirements can easily be wiped out when market values start to plunge.

The interviewees said that market valuation influenced Viking Bank to such an extent that they were unclear about the bank's performance. They said the markets reflexively reinforce ups and downs (see Soros, 2003; 2009), which creates volatile numbers. A branch manager echoed this criticism of market valuation that created unreliable paper values:

I think the models for market valuation are too flexible. We no longer use the prudence concept that we used before. We have a portfolio of venture capital investments that we are supposed to write up or down, depending on some model. In my world, I think this is being a bit aggressive. I think that in the area of venture capital, you take a decline directly. In an upswing you sell because then you have the cash. The system no longer works that way, and thus there is greater volatility. There is a risk that paper values are inflated. Market values are certainly creating a swing for us.

In summary, Viking Bank managers faced a difficult situation in the financial crisis of 2008-2009. The bank was experiencing losses that required it to reserve funds to meet the Basel II capital requirements. Viking Bank had also converted its management accounting information system into a risk measurement system. In this conversion, the Management Accounting Department employees were assigned risk measurement duties in order to meet the reporting requirements outlined in Basel II. Yet, as the losses increased, Viking Bank managers questioned the value of the new system. They thought they lacked reliable information for use in making loans. This situation, of course, had implications for other staff members.

\section{Discussion}

The purpose of this article is to assess management's perspective on the effectiveness of the risk measurement system under Basel II. Viking Bank managers initially thought this risk measurement system would warn them in time to avoid future financial crises. Yet in the financial crisis of 2008-2009, following the failure of Lehman Brothers, senior bank managers realized that market values of assets held as collateral for loans were unrealistically high. They became sceptical of the information provided by the risk management system. As the support for the risk measurement system weakened, Viking Bank turned to the use of Expert Judgment to evaluate collateral asset value and credit risk.

From a banking regulatory point of view, lack of trust in a risk measurement system is problematic. Complicating the problem is that a bank may lack good alternatives to its risk measurement system. The incentives offered by Basel II were so tempting that Viking Bank managers felt market pressure to implement a risk measurement system prescribed by Basel II. Yet when the financial crisis arose, it was difficult to find an alternative to their risk measurement system. 
Career advancement prospects for risk management staff members at Viking Bank were discouraging. There was little opportunity for them to advance to top management positions at the bank. Their only hope for promotion was to move to another area of the bank.

With decreasing faith in the risk management system, Viking Bank looked for other sources of risk information. The solution was to rely more on the Expert Judgment of managers when making loans and valuing collateral. As a consequence, Viking Bank may have found itself in the curious position of providing information to the national regulatory authority based on the risk measurement system that differs from the information they use in practice. This divergence is hardly the intention of Basel II.

More research is needed in this area. We need to know more about how knowledge is transferred between staff members in banks. The lack of reliable information indicates that private channels for exchanging information are important. Because financial crises are recurrent, it is important to retain the knowledge acquired in previous crises. In some banks there is a new management team every fifteen years. In other banks, management remains essentially unchanged, and replacements, when necessary, are internally recruited. In both cases it is necessary to transfer knowledge from experienced people to novices. However, we do not know very much about this process.

The interviews were conducted during a severe global financial crisis. Therefore, the data provide insights that are exceptional given that global financial crises of this magnitude are rare. Many banks faced very serious problems, especially when it was known that Lehman Brothers failed. The crisis was more a turning point for Viking Bank in that it survived. It was, nevertheless, a very sensitive situation to approach some of their top bank managers and ask them about risk measurement that has both regulatory and management implications. The author's presence could have influenced the interviewees' responses (see Miles \& Huberman, 1994) such that their responses may not necessarily be the "windows into the depth of reality" that Czarniawska (2007: 13) describes. The interviewees may have responded in ways they thought the interviews expected. This is a possible limitation of the study, although the problem may have been mitigated somewhat by the number and variety of interviewees.

\section{References}

Basel Committee on Banking Supervision. (1999). A new capital adequacy framework. Bank for International Settlements, Basel.

Basel Committee on Banking Supervision. (2001a). Consultative document, Pillar 3 (Market discipline), Supporting document to the New Basel Capital Accord, issued for comment by 31 May 2001. Bank for International Settlements, Basel.

Basel Committee on Banking Supervision. (2001b). The new Basel Capital Accord: An explanatory note. Bank for International Settlements, Basel.

Basel Committee on Banking Supervision. (2004). International convergence and capital measurement and capital standards. A revised framework. Bank for International Settlements, Basel.

Beck. U. (1992). Risk in society. London: Sage Publications.

Bhimani, A. (2009). Risk management, corporate governance, and management accounting: Emerging interdependencies. Management Accounting Research, 20 (1), 2-5. http://dx.doi.org/10.1016/j.mar.2008.11.002

Bromwich, M., \& Hong, C. (2000). Costs and regulation in the U.K. telecommunications industry. Management Accounting Research, 11 (3), 137-165. http://dx.doi.org/10.1006/mare.2000.0124

Bryman, A., \& Bell, E. (2003). Business research methods. Oxford: Oxford University Press.

Cerny, P.G. (1994). The infrastructure of the infrastructure? Toward embedded financial orthodoxy in the international political economy. In R.P. Palan, \& V. Gilles (Eds.), Transcending the state - global divide (pp. 208-211). Boulder, CO: Lynne Rienner.

Chua, W.F. (1996). Teaching and learning only the language of the numbers - Monolingualism in a multilingual world. Critical Perspectivies on Accounting, 7(3), 129-156. http://dx.doi.org/10.1006/cpac.1996.0019

Committee on Payment and Settlement Systems. (2001). A glossary of terms used in payments and settlements systems. Bank for International Settlements, Basel.

Czarniawska, B. (2007). Shadowing and other techniques for doing fieldwork in modern societies. Malmö: Liber.

Danielsson, J. (2002). The emperor has no clothes: Limits to risk modelling. Journal of Banking and Finance, 26(7), 1273-1296. http://dx.doi.org/10.1016/S0378-4266(02)00263-7 
Directive 2006/48/E. European Union, Brussels.

Directive 2006/49/E. European Union, Brussels.

Glaser, B.G., \& Strauss, A.L. (1967). The discovery of grounded theory: Strategies for qualitative research. New York: Aldine de Gruyter.

Hartley, J. (2004). Case study research. In C. Cassell, \& G. Symon (Eds.), Essential guide to qualitative methods in organizational research (pp. 323-333). London: Sage.

Kaplan, R.S. (2009). Risk management and the strategy execution system. Balanced Score Card Report, 11(1), 1-6.

Kapstein, E. (1989). Resolving the regulator's dilemma: International coordination of banking regulations. International Organization, 43(3), 323-347. http://dx.doi.org/10.1017/S0020818300032938

King, N, (2004). Using interviews in qualitative research. In C. Cassell, \& G. Symon (Eds.), Essential guide to qualitative methods in organizational research (pp. 11-23). London: Sage.

Kvale, S. (1983). The qualitative research interview: A phenomenological and a hermeneutical mode of understanding. Journal of Phenomenology Psychology, 14(2), 171-96. http://dx.doi.org/10.1163/156916283X00090

McGoun, E. G. (1992). The CAPM: a Nobel failure. Critical Perspectives on Accounting, 4(2), 155-177. http://dx.doi.org/10.1006/cpac.1993.1010

McGoun, E. G, (1995). The history of risk measurement. Critical Perspectives on Accounting, 6(6), 511-532. http://dx.doi.org/10.1006/cpac.1995.1047

Mikes, A. (2009). Risk management and calculative cultures. Management Accounting Research, 20(1), 18-40. http://dx.doi.org/10.1016/j.mar.2008.10.005

Mikes, A. (2011). From counting risk to making risk count: Boundary-work in risk management. Accounting, Organizations and Society, 36(4/5), 226-245. http://dx.doi.org/10.1016/j.aos.2011.03.002

Miles, M. B., \& Huberman, A. M. (1994). Qualitative data analysis: An expanded sourcebook (2nd ed.). Thousand Oaks, CA: Sage.

Power, M. (2004). Risk management of everything. London: Demos.

Power, M. (2007). Organized uncertainty - Designing a world of risk management. Oxford: Oxford University Press.

Power, M. (2009). The risk management of nothing. Accounting, Organizations and Society, 34(6/7), 849-855. http://dx.doi.org/10.1016/j.aos.2009.06.001

Soros, G. (2003). The alchemy of finance. New York: John Wiley

Soros, G. (2009). Crash of 2008 and what it means - The new paradigm for financial markets. United Kingdom: The Perseus Book Group.

The Financial Crisis Inquiry Report. (2011). US Government Printing Office, Washington.

Wall Street and the Financial Crisis: Anatomy of a Financial Collapse. (2011). Permanent Subcommittee on Investigations, Washington.

Wahlström, G. (2009). Risk management versus operational action: Basel II in a Swedish context. Management Accounting Research, 20(1), 53-68. http://dx.doi.org/10.1016/j.mar.2008.10.002

Woods, M. (2009). A contingency theory perspective on the risk management control system within Birmingham City Council. Management, Accounting Research, 20(1), 69-81. http://dx.doi.org/10.1016/j.mar.2008.10.003 


\section{Notes}

Note 1. Consider two banks. Bank A has a capital requirement of 5, and Bank B has a capital requirement of 2,5. If an investor demands a 50\% return, Bank A has to pay 2,5 while Bank B needs to pay only 1,25. Bank B can be more competitive and thus can take market share from A. It is not difficult to see why Basel II, with its incentives, would appeal to a shareholder-oriented bank, such as the bank in this study.

Note 2. Viking Bank is a fictitious name. The interviewees were granted anonymity.

Note 3. Accounting for regulated industries is an important area of accounting research. Accounting systems in industries other than banks have been investigated in order to examine specific problems militating acceptance in practice (Bromwich \&Hong, 2000). More research in the field of regulation and management practice is recommended for other highly regulated industries including banks (Bromwich \& Hong, 2000).

Note 4. Credit risk is: "The risk that a counterpart will not settle an obligation for full value, either when due or at any time thereafter." (Committee on Payment and Settlement Systems, 2001: 11). Market risk is: "The risk of losses in onand off-balance sheet positions arising from movements in market prices." (Committee on Payments and Settlement Systems, 2001: 25). Operational risk is: "The risk of loss resulting from inadequate or failed internal processes, people and systems or from external events. This definition includes legal risk, but excludes strategic and reputational risk." (Basel Committee on Banking Supervision, 2004: 137).

Note 5. At Viking Bank, which has no longer has a Management Accounting Department, certain employees have both accounting and financial responsibilities. Among these responsibilities are financial reporting (including asset/liability valuation), budgeting, and reporting risk-adjusted yields to management. These people also prepare the reports for the national regulatory authority. 